\title{
Perspektif Pasien dan Manajemen tentang Mutu Pelayanan IGD
}

\author{
Dicky Fachriza ${ }^{1}$, Destanul Aulia ${ }^{2}$, Kintoko Rochadi ${ }^{3}$ \\ ${ }^{1,2,3}$ Fakultas Kesehatan Masyarakat, Universitas Sumatera Utara, Indonesia \\ Email: tesisarsdicky@gmail.com
}

\begin{abstract}
Patient and Management Perspective about Quality Emergency Installation Services. The basic principle of a hospital is fulfilling the needs and demand of patients who hope that their health problems can be settled in a hospital. They expect ready, quick, responsive, and comfortable services. Patient satisfaction can be influenced by the health care quality of health care providers who sympathize, respect, and respond to their needs. The research used a qualitative method. The data were gathered by conducting participant observation, and in-depth interviews. The research subjects were 4 informants, IGD (emergency room) personnel and IGD patients in Prima Inti Medika hospital. The result of the research, in the pre-service, showed that nurses' response was quick, complaints were responded well, the process of inpatient and outpatient was good, nurses' cooperation was good, and the personnel was accredited; but, the facility was inadequate and incentives were lower than the government's standard. From the patients' perspectives, it was found that pre-service was in accordance with SOP, the process of doctors'and pharmacy's service was good, but nurses' service and IGD facility were unsatisfactory, nurses' cooperation was good, but their competence and quality were inadequate.
\end{abstract}

Keywords: Emergency installation, Patients perspectives, Service quality

\begin{abstract}
Abstrak: Perspektif Pasien dan Manajemen tentang Mutu Layanan IGD. Hakikat dasar dari rumah sakit sebagai pemenuhan kebutuhan dan tuntutan pasien yang mengharapkan penyelesaian masalah kesehatannya pada rumah sakit. Pasien mengharapkan pelayanan yang siap, cepat, tanggap dan nyaman terhadap keluhan penyakit pasien. Kepuasan pasien dapat dipengaruhi oleh mutu pelayanan kesehatan yang diberikan oleh rumah sakit sebagai provider, dimana mutu pelayanan kesehatan bagi pasien berarti empati, respek dan tanggap akan kebutuhannya. Jenis penelitian kualitatif dengan teknik pengumpulan data participant observation dan in depth interview. Informan penelitian ini sebanyak 9 orang yang terdiri dari 6 (enam) orang petugas IGDdan 3 pasien IGD RS Prima Inti Medika. Hasil penelitian menunjukkan berdasarkan pra pelayanan respon perawat lebih cepat, keluhan ditanggapi dengan baik oleh perawat, proses perawatan rawat inap maupun rujukan sudah bagus, kerjasama perawat berjalan baik, petugas sudah terakreditasi, tetapi fasilitas belum memadai, imbalan dibawah ketetapan pemerintah. Dari perspektif pasien, pra pelayanan sesuai SOP, proses pelayanan tindakan penerimaan dokter dan farmasi baik, tetapi pelayanan perawat dan fasilitas IGD kurang memuaskan, kerjasama perawat sudah bagus, tetapi kompetensi dan kualitas perawat masih kurang. Berdasarkan manajemen rumah sakit, kompetensi teknis telah mengikuti standar layanan kesehatan, petugas mampu dalam mengurangi keluhan pasien, IGD RS Prima Inti Medika telah dapat melayani pasien sesuai dengan kebutuhannya, tetapi keamanan belum maksimal dan pasien tidak merasa nyaman saat dirawat di IGD RS Prima Inti Medika.
\end{abstract}

Kata Kunci: IGD, Perspektif pasien, Mutu pelayanan

\section{PENDAHULUAN}

Pelayanan kesehatan merupakan hak setiap orang yang dijamin dalam undang-undang Tahun 1945 yang harus diwujudkan dengan upaya peningkatan derajat kesehatan yang setinggitingginya. Undang-Undang Nomor 44 Tahun 2009 tentang Rumah Sakit menjelaskan bahwa rumah sakit adalah institusi pelayanan kesehatan bagi masyarakat dengan karakteristik tersendiri yang dipengaruhi oleh perkembangan ilmu pengetahuan kesehatan, kemajuan teknologi, dan kehidupan sosial ekonomi masyarakat yang harus tetap mampu meningkatkan pelayanan yang bermutu dan terjangkau oleh masyarakat agar terwujud derajat kesehatan yang setinggi-tingginya (Nena, 2015).

Hakikat dasar dari rumah sakit adalah pemenuhan kebutuhan dan tuntutan pasien yang mengharapkan penyelesaian masalah kesehatannya pada rumah sakit. Pasien memandang bahwa hanya 
rumah sakit yang mampu memberikan pelayanan medis sebagai upaya penyembuhan dan pemulihan atas rasa sakit yang dideritanya. Pasien mengharapkan pelayanan yang siap, cepat, tanggap dan nyaman terhadap keluhan penyakit pasien. Kepuasan pasien dapat dipengaruhi oleh mutu pelayanan kesehatan yang diberikan oleh rumah sakit sebagai provider, dimana mutu pelayanan kesehatan bagi pasien berarti empati, respek dan tanggap akan kebutuhannya. Dalam hal ini kebutuhan pelayanan yang diberikan oleh petugas kesehatan, sedangkan mutu pelayanan kesehatan bagi petugas berarti bebas melakukan segala sesuatu secara profesional. Untuk meningkatkan derajat kesehatan pasien dan masyarakat sesuai dengan ilmu pengetahuan dan keterampilan yang memadai serta terlindungi oleh aturan perundangundangan yang berlaku. Upaya rumah sakit untuk tetap bertahan dan berkembang adalah dengan meningkatkan pelayanan kepada pasien yang sesuai dengan ketentuan atau Standar Pelayanan Rumah Sakit sebagaimana yang ada dalam Keputusan Menteri Kesehatan Republik Indonesia Nomor: 1333/Menkes/SK/XII/1999 tentang Standar Pelayanan Rumah Sakit (Mulyadi, 2013).

Perkembangan manajemen mutu di bidang pelayanan kesehatan khususnya pelayanan rumah sakit masih dirasakan kurang, hal ini dapat kita lihat dari konflik yang terjadi antara pelayanan dan pelanggan yang menunjukkan kecenderungan meningkat, salah satunya adalah mutu pelayanan yang diberikan tidak memuaskan konsumen/ pelanggan (Yoestandri dalam Imam Sujono, 2015).

Penanganan kasus yang memerlukan kecepatan dan kecekatan sangat diperlukan dalam upaya menyelamatkan jiwa seorang pelanggan. Pelayanan rumah sakit yang sangat berhubungan dengan penanganan yang cepat dan segera adalah pelayanan kasus-kasus gawat darurat, sehingga instalasi gawat darurat rumah sakit sangat penting keberadaannya dan juga harus diperhatikan mutu pelayanannya. Banyak sekali kasus-kasus pelayanan gawat darurat yang masih kurang penanganannya karena beberapa aspek, antara lain pelayanan yang kurang cekatan, petugas yang kurang profesional, serta fasilitas dari rumah sakit tersebut yang dapat menghambat pemberian pelayanan yang baik (Imam Sujono, 2015).

Berdasarkan data Kementerian Kesehatan Republik Indonesia (2018) jumlah Rumah Sakit di Indonesia sebanyak 2776 terdiri atas 2198 RSU (Rumah Sakit Umum) dan 578 RSK (Rumah Sakit Khusus). Menurut Wibowo (2016) rata-rata pasien IGD pada tahun 2012 sebanyak 291.025, tahun 2013 sebanyak 265.307, tahun 2014 sebanyak 346.717 dan pada tahun 2015 sebanyak
202.788. Terdapat penurunan jumlah pasien IGD yang cukup signifikan antara tahun 2014 sampai dengan tahun 2015 yaitu sebesar 41,5\%. Ratarata pasien tersebut merupakan pasien rujukan dari Rumah Sakit Provinsi.

Dari survei awal yang peneliti lakukan, selama empat tahun belakangan ini pasien yang memanfaatkan pelayanan IGD di RS Prima Inti Medika berdasarkan data kunjungan pasien semakin menurun. Angka kunjungan pada IGD tahun 2014 menunjukkan: 1865 pasien, tahun 2015: 1516 pasien, tahun 2016: 1436 pasien, dan tahun 2017: 1373 pasien. Penurunan angka rujukan ini diasumsikan bahwa adanya berbagai masalah yang dialami pasien sehingga berdampak pada berkurangnya pemanfaatan pelayanan IGD di RS Prima Inti Medika yang menjadi unggulannya.

Berdasarkan hasil wawancara awal dengan pasien berjumlah 30 orang pada Instalasi Gawat Darurat RS Prima Inti Medika pada tanggal 10 Januari 2018, diketahui banyaknya keluhan mengenai kualitas pelayanan di instalasi tersebut. Keluhan tersebut antara lain adalah: 1) Masih kurang sesuai harapan terhadap tenaga medis dalam menangani masalah gawat darurat pasien; 2) Keterlambatan dalam menangani pasien; 3) Masih belum yakin dengan pelayanan rumah sakit karena rumah sakit masih tergolong baru; 4) Ketidakjelasan informasi tentang tindakan medis yang diberikan kepada pasien; dan 5) Adanya dugaan pasien atau keluarga pasien terhadap kesalahan tindakan medis yang dilakukan oleh petugas RS Prima Inti Medika.

Semua keluhan ini membuat citra Rumah Sakit semakin tidak baik. Keluhan-keluhan tentang kualitas ini menjadi masalah yang harus diperhatikan oleh pihak manajemen RS Prima Inti Medika untuk menjaga kualitas dan mutu pelayanan sehingga pasien yang memanfaatkan pelayanan kesehatan di RS Prima Inti Medika dapat meningkat. Hal ini sesuai dengan pendapat Green (1980) bahwa ada tiga faktor yang mempengaruhi pemanfaatan yaitu faktor predisposisi (predisposing factor), faktor pemungkin (enabling factor), faktor penguat (reinforcing factor).

Rendahnya kualitas pelayanan di Instalasi Gawat Darurat di RS Prima Inti Medika mengakibatkan masyarakat mencari alternantif fasilitas kesehatan lainnya sehingga tidak menjadi pilihan prioritas dalam memanfaatkan pelayanan kesehatan. Masyarakat beralih mencari rumah sakit lain yang bisa memenuhi harapan dan keinginannya ketika terjadi kondisi darurat. Ini mengindikasikan bahwa masyarakat kurang percaya terhadap kualitas pelayanan kesehatan yang diberikan. 


\section{METODE}

Penelitian ini menggunakan pendekatan deskriftif kualitatif dengan tujuan untuk memperoleh gambaran yang komprehensif dan mendalam tentang mutu pelayanan IGD, perspektif pasien dan manajemen di RS Prima Inti Medika. Penelitian kualitatif merupakan prosedur penelitian yang menghasilkan data deskriptif berupa kata-kata tertulis atau lisan dari orang-orang dan perilaku yang dapat diamati. Dengan penelitian menggunakan pendekatan deskriftif kualitatif, peneliti akan dapat menggambarkan atau mendeskripsikan fenomena-fenomena yang ada secara aktual serta mengembangkan konsep dari menghimpun fakta tetapi tidak melakukan pengujian hipotesa. Metode pendekatan dan cara yang akan digunakan dalam memperoleh data atau fenomena yang ingin diungkap dalam penelitian ini adalah dengan menggunakan pendekatan studi kasus.

Karakteristik informan yang digunakan dalam penelitian ini dipilih secara purposive (berdasarkan representasinya terhadap penelitian) yaitu sebagai informan utama adalah Kepala Unit IGD dan Kepala Perawatan IGD. Informan triangulasi adalah 2 orang perawat IGD RS Prima Inti Medika, 1 orang Asisten Apoteker Instalasi Farmasi, 1 orangAdministrasi Keuangan IGD RS Prima Inti Medika dan 3 orang pasien IGD RS Prima Inti Medika. Teknik pengolahan data menggunakan metode analisis isi (content analysis). Jumlah informan dalam penelitian ini sebanyak 9 (Sembilan) orang.

Penelitian ini akan dilakukan di RS Prima Inti Medika, karena terdapat kemudahan bagi peneliti dalam menemukan kasus. Dengan pertimbangan bahwa peneliti adalah salah seorang karyawan di RS Prima Inti Medika tersebut, selain itu peneliti dapat berinteraksi dengan mudah dan mengenal informan dengan baik. Hal ini memberi manfaat dan kemudahan dalam membina hubungan saling percaya dengan informan dan penelitian ini belum pernah dilakukan sebelumnya di RS Prima Inti Medika. Penelitian ini dilakukan pada bulan Agustus sampai dengan Oktober 2018. Analisis data yang dilakukan sesuai dengan Miles dan Huberman dalam Sugiyono (2012), yaitu :

1. Pengumpulan Data: Data-data yang diperoleh dari aneka macam cara (observasi, wawancara, dokumentasi, pita rekaman dan lain-lain) dikumpulkan kemudian direduksi atau dipilahpilah.

2. Reduksi Data: Diartikan sebagai proses pemilihan, perumusan, perhatian pada penyederhanaan, pengabstrakan dan informasi data kasar yang muncul dari catatan tertulis di lapangan.

3. Penyajian Data: Sekumpulan informasi yang telah tersusun secara terpadu dan sudah dipahami yang memberi kemungkinan adanya penarikan kesimpulan dan pengambilan tindakan.

4. Menarik kesimpulan verifikasi dari berbagai temuan data yang diperoleh selama proses penelitian berlangsung

\section{HASIL}

Hasil penelitian yang diperoleh dari wawancara dapat memberikan gambaran tentang mutu pelayanan IGD.

\section{Hasil Wawancara terhadap Aktivitas Pra Pelayanan di IGD}

Dari hasil wawancara dengan petugas IGD RS Prima Inti Medika terkait pelayanan apa saja yang dipersiapkan dalam penatalaksanaan pelayanan sebelum menerima pelayanan di IGD;

Menurut Informan 1,

Yang pertama otomatis tenaga yang ditugasi itu harus siap. Dalam 5 menit pasien harus disiapkan dari pertama sampai melaksanakan pelayanan kita. Kemudian perawat yang bertugas melakukan vital sign baru melaporkan kepada dokter yang bertugas di IGD. Dari dokter yang bertugas di IGD baru tindakan apa yang harus kita lakukan selanjutnya. Itu yang paling utama. Selain itu alat-alat yang ada di IGD misalnya kita lihat kegawatdaruratan pasiennya dimana kita tempatkan di drase merahkah, di drase kuningkah, didrase hijaukah, itu harus kita lihat. Kalau memang di drase kuning, apa saja yang harus dilakukan oleh petugasnya. Misalnya dengan keluhan febris, menunggu dari instruksi dokter apa yang harus kita lakukan setelah kita melakukan vital sign. Acuannya yang pertama vital sign dulu yang harus kita lakukan.

Menurut Informan 2,

Persiapan yang utama di IGD itu memang sarana dan prasarana. Seperti ruangan IGD. IGD itu memiliki beberapa item ruangan misalnya ruang administrasi, ruang triase, ruang penyimpanan barang atau rak atau locker, ruang resusitasi pasien, serta 
kita menyiapkan seperti parkir. Terus untuk tenaga sdmnya kita memperhatikan juga untuk persiapan kita d IGD yaitu memang yang benar-benar mempunyai pelatihan minimal memiliki BPJLS atau pengertian emergency seperti BPGD SPBDT.

Menurut Informan 3,

Pertama-tama kita siapkan ruangan dan tiket kita siapkan semua, baik itu alat, steril alat, kesiapan PHP, dan staf-staf lainnya kita persiapkan.

Menurut Informan 4,

Pertama dari pasien yang masuk kita tanya dia karyawan atau bukan, alamatnya dimana, kemudian apa ada pakai askes atau tidak. Perawat IGD sebelumnya mempersiapkan oksigen alat gawat darurat seperti hecting, isntrumen yang berhubungan dengan gawat darurat. Selain itu diperlukan respon time berapa standartnya, dokter harus stand by 24 jam, akses penerimaan pasien. Untuk sekarang promosi keamanan belum ada, untuk parkir belum diambil tarif.

Menurut Informan 5,

Yang paling penting obat, terus bahan pendukungnya untuk kita melayani pasien, kemudian harus ada e-tiket agar pasien lebih mengerti. Jika pasien sampai di rumah, kalau hanya kita bilang begitu saja, pasiennya tidak terekam habis, harus kita buat juga pencatatannya untuk pasiennya. Selain itu di bidang farmasi yang harus disiapkan SOP. SOP ini perlu dari pertama kita menerima resep itu sudah dimulai dari SOP-nya yang sudah kita buat dari instalasi farmasi, seperti pada saat obat masuk kita lihat kelengkapan resepnya, setelah itu kita lihat obatnya, di farmasi ada atau tidak obat yang telah disiapkan oleh dokter. Apabila tidak ada, kita konfirmasi lagi ke dokter obat apa yang bisa diganti untuk obat yang tidak tersedia di farmasi. Selain itu kita berikan ke pasien beserta edukasinya.

Menurut Informan 6,

Pertama terkait IGD jadi mungkin yang pertama pra pelayanan itu ada persoalan fasilitas yang memadai untuk pra pelayanan itu persoalan misalnya tempat parkir, jalur masuk, kemudian ada penyambutan perawatnya.

\section{Hasil Wawancara terhadap Proses Pelayanan di IGD}

Terkait proses pelayanan di IGD, tindakan petugas dalam penerimaan pasien IGD RS Prima Inti Medika menurut petugas IGD RS Prima Inti Medika;

Menurut Informan 1, "Saat penerimaan pasien di IGD tergantung instruksi dari dokternya. Setelah kita vital sign, kita siapkan alat-alat untuk pemasangan infus itu apa saja".

Menurut Informan 2,

"Tindakan penerimaan di IGD itu kita respons time, lebih cepat, kita langsung menanyakan bila pasien dengan gawat darurat kita ada standarisasinya yaitu dengan cara langsung menanyakan misalkan pasien kecelakaan, kita langsung menyentuh pasien dengan memanggil dengan kurang lebih waktu 10 detik itu harus kita layani segera karena pasien gawat darurat. Apabila terjadi dengan jantung kita harus lakukan resusitasi”.

Menurut Informan 3,

"Penerimaan pertama saya tanya dulu keluhannya, setelah tahu kita apa keluhannya kita periksa tanda-tanda vitalnya yang sederhana setelah itu baru kita konsulkan ke dokter".

Menurut Informan 4,

"Pertama kita tanya keluhannya apa. Jadi kalau misalnya tadi keluhannya sesak, pertolongan pertamanya itulah oksigen".

Menurut Informan 5,

"Kita menjelaskan pada pasien obat apa yang kita berikan ke pasien. Hal ini atas dasar instruksi dokter. Selanjutnya kita bertanya pada pasien apakah sudah mengerti dengan penjelasan kita tadi. Pegawai instalasi tidak standby di IGD karena petugasnya hanya 1 orang, jadi kalau ada panggilan kita baru ke $I G D ”$.

Menurut Informan 6

"Selama ini saya lihat pelayanan sudah maksimal. Cara menyambut pasien juga sudah bagus kemudian proses treatmentnya juga bagus. Cuman mungkin kadang-kadang masih ada budaya dari masyarakat yang kurang mendukung". 


\section{Hasil Wawancara Pasca Pelayanan di IGD}

Dari hasil wawancara dengan beberapa petugas IGD RS Prima Inti Medika pasca pelayanan di IGD setelah tindakan yang dilakukan di IGD;

Menurut Informan 1,

Setelah selesai semua, apabila pasien tidak perlu kita rujuk, kita mengarahkan kepada pasien untuk melakukan (setelah semua sudah lengkap), kita anjurkan ke kasir.

Menurut Informan 2,

Pasca pelayanan kita menanyakan kembali kepada pasien bagaimana keluhan pasien tersebut apakah dia merasa ada kepuasan terhadap pelayanan kita, atau pasien merasa ada masalah dengan penyakitnya. Apabila pasien belum merasa puas dengan pelayanan kita, kita menanyakan kembali apakah pasien mau dilanjutkan ke ruang perawatan ataupun dilakukan observasi.

Menurut Informan 3,

Tergantung instruksi dokter yang menjaga, kalau misalnya konsul atau dirawat inap, kita siapkan pasiennya untuk dirawat inap dan kita laporkan ke ruangan untuk disiapkan ruangan.

Menurut Informan 4,

Kalau sekiranya memang keluhannya itu lebih parah pasien harus rawat inap, tetapi apabila sudah mendingan pasien harus rawat jalan. Sebelumnya kita konfirmasi dulu ke pasien.

Menurut Informan 5,

Kalau misalnya untuk pasien rawat jalan, obat itu kita siapkan dan kita berikan ke pasiennya. Kalau ke rawat inap, kita serahkan ke perawatnya. Selanjutnya perawat yang menyerahkan ke pasiennya. Baik obat injeksi maupun obat oral.

Menurut Informan 6,

Jadi kalau saya lihat pasca pelayanan itu ada 3 jenis tindakan, yang pertama adalah pasien sembuh, artinya ketika mereka sampai di IGD masalah mereka terselesaikan dan mereka bisa pulang. Yang kedua mereka harus dirawat inap. Itu prosesnya lumayan panjang, karena memang ada urusan administrasi yang harus diselesaikan oleh keluarga pasien. Atau yang ketiga, yang ketiga ini dengan rujukan. Jadi seandainya pasien tidak dapat ditangani di IGD dan tidak bisa ditangani oleh rumah sakit, maka akan diberikan rujukan. Nah kalau saya lihat, proses rujukannya sudah bagus, kemudian proses untuk masuk ke rawat inapnya juga sudah bagus, kemudian banyak pasien yang sembuh juga ada. Jadi saya rasa sudah standard. Selain itu belum ada pasien follow up yang sudah pulang terus dicall control lagi sebulan setelah perawatan. Karena pertama kita belum punya layanan call center. Jadi di IGD itu hanya sebatas nomor telepon untuk panggilan jemput ambulan. Jadi belum melayani tentang keluhan pelanggan. Dan mungkin masyarakat juga belum tahu bahwa IGD kita juga punya sistem layanan pelanggan seperti itu, karena itu harus diterjemahkan dalam bisnis pelayanan kita. Saya lihat itu belum ada.

\section{Hasil Wawancara berdasarkan Dukungan Pelayanan di IGD}

Dukungan pelayanan berdasarkan budaya kerja di IGD RS Prima Inti Medika untuk saat ini;

Menurut Informan 1,

Menurut saya masih kurang, karena yang pertama masih kurangnya pasien mungkin, selain itu yang kita layani selama ini juga bukan pasien yang benar-benar punya kegawatdaruratan, misalnya cuma yang ada disini yang kita sering febris yang paling banyak, jadi tindakan-tindakan yang biasa kita lakukan itu-itu aja. Jadi kurang tantangan.

Menurut Informan 2,

Untuk saat ini budaya kerjanya sudah berjalan baik, karena kita cepat merespon untuk melayani pasien, antara sesama perawat juga terjalin hubungan kerja yang baik, hubungan petugas dengan dokter juga terjalin baik, dengan stakeholder yang lain juga baik. Dapat dikatakan sistem budaya kerja yang baik sudah berjalan di IGD.

Menurut Informan 3,

Sudah lumayan baik, ada kerjasama, ada koordinasi. Paling masalah antara ruang IGD ke rawat inap itu kan sudah diselesaikan, apa permasalahannya sudah diselesaikan, kayak masalah injeksi yang harusnya di IGD. Cuman kemarin karena mis komunikasi jadi dilakukan di rawat inap. Tapi sekarang sudah clear. 
Menurut Informan 4,

Sudah sesuai semua, terutama saat penyambutannya.

Menurut Informan 5,

Dari segi komunikasi cukup baik. Selama saya berada di sana juga pasiennya cukup puas, yang kita lihat ya. Pasien pulang dengan senyum, mengucapkan terima pada kita. Tidak ada yang mengecewakanlah. Pasien terlihat puas.

Menurut Informan 6,

Jadi kalau kita melihat usia masa operasional rumah sakit yang belum lama, karena kita baru saja penerimaan di bulan September, jadi memang budaya kerja itu belum terbentuk secara resmi ofisial, tapi memang ada proses untuk membentuk budaya itu dengan kuat. Masalahnya ada di pemahaman atau persepsi perawat-perawat IGD. Jadi kalau saya lihat memang antar perawat belum mempunyai pemahaman yang sama tentang pelayanan. Kalau kita melihat ada perawat yang punya gimmick yang bagus kepada pasien nah ada juga kemudian perawat yang tidak punya gimmick yang bagus standard. Memang budaya itu belum tercipta sempurna tapi saya lihat sudah mengarah. Kalau saya lihat proses knowledge antara perawat tidak ada, karena memang setiap perawat itu punya locus control masing-masing. Dia punya istilah locus control, istilahnya ketika dia menghadapi pasien, pasien puas atau tidak itu bisa disebabkan oleh karena dia atau karena lain hal. Memang itu tergantung kepada tipe kepribadian juga. Ada perawat misalnya tipe kepribadiannya A atau B. tipe $B$ cenderung lebih atraktif, sedangkan tipe $A$ itu mungkin lebih pendiam. Nah itu memang setiap orang punya tipe karakteristik masing-masing dan itu bergantung pada locus controlnya masing-masing. Kalau saya lihat itu prosesinya tidak bisa disamakan, karena setiap perawat mungkin berusaha untuk memberikan yang lebih untuk dirinya sendiri, tapi karena budaya tadi belum tercipta secara sempurna, sehingga jadi kesatuan gimmick itu belum sempurna.

\section{Perspektif Pasien}

Perspektif pasien berdasarkan hasil wawancara pra pelayanan oleh perawat di IGD RS Prima Inti Medika, pasien berharap dalam penatalaksanaan pelayanan sebelum menerima pelayanan di IGD

Menurut Informan 7,

Untuk IGD saya harapkan itu akses menuju IGD-nya gampang dijangkau lancar juga, kemudian parkir, gampang diakses, kemudian masalah keamanan juga yang baguslah, bisa menjamin keamanan si pasien. Untuk pelayanan diharapkan dokter lengkap selalu ada 24 jam. Begitu juga dengan perawat yang berpengalaman dan cekatan dengan penanganan pasien.

\section{Manajemen IGD RS Prima Inti Medika}

Manajemen IGD RS Prima Inti Medika dalam penelitian ini dilihat berdasarkan kompetensi teknis, keterjangkauan atau akses, efektivitas, efisien, kesinambungan, keamanan dan kenyamanan. Hal ini seperti yang diungkapkan oleh petugas yaitu Kepala IGD RS Prima Inti Medika (Informan 2):

Tindakan penerimaan di IGD itu kita respons time, lebih cepat, kita langsung menanyakan bila pasien dengan gawat darurat kita ada standarisasinya yaitu dengan cara langsung menanyakan misalkan pasien kecelakaan, kita langsung menyentuh pasien dengan memanggil dengan kurang lebih waktu 10 detik itu harus kita layani segera karena pasien gawat darurat. Apabila terjadi dengan jantung kita harus lakukan resusitasi.

\section{PEMBAHASAN}

\section{Mutu Pelayanan IGD RS Prima Inti Medika}

Dari hasil wawancara dengan petugas IGD RS Prima Inti Medika terkait mutu pelayanan IGD pada saat pra pelayanan sebelum menerima pasien menunjukkan petugas IGD sudah melakukan persiapan seperti sarana dan prasarana seperti akses menuju ke IGD, persiapan alat-alat yang berhubungan dengan kode warna kegawatdaruratan. Hal ini sesuai dengan pembagian penanganan dan kriteria pasien dalam kondisi kegawatdaruratan. Pemilihan warna kegawatdaruratan bisa saja disesuaikan dengan kebijakan, kebiasaan atau kesepakatan di masing-masing RS agar tidak menimbulkan kerancuan terkait dengan kode warna. Tetapi yang harus diingat adalah makna dari tiap-tiap huruf tersebut. Dengan penerapan metode screening ini maka petugas sudah bisamenyingkirkan kasus-kasus bukan gawat 
darurat. Selanjutnya pasien dengan kode A langsung ditangani oleh petugas khusus untuk rawat inap sedangkan pasien dengan kode $\mathrm{E}$ dapat langsung mengaktifkan sistem perawatan oncall dan home care. Dengan demikian UGD hanya fokus pada pasien dengan kode B, C dan D.

Selanjutnya melakukan tindakan sesuai dengan instruksi dokter, mempersiapkan petugas yang sudah pernah diberikan pelatihan minimal memiliki BPJLS, melakukan vital sign terlebih dahulu, mempersiapkan ruangan, alat, kesiapan PHP, dan staf-staf yang terlatih. Selain itu diperlukan respon time berapa standarnya, dokter harus stand by 24 jam, akses penerimaan pasien. Persiapan awal sebelum menerima pasien sudah sesuai dengan SOP. Persiapan awal ini perlu dilakukan untuk mengetahui kondisi awal pasien, bila terjadi emergency petugas cepat tanggap dalam memberikan pelayanan. Selain sebagai bantuan anamnesa, seandainya terjadi sesuatu petugas IGD bekerja sudah sesuai dengan SOP yang ditetapkan rumah sakit.

Persiapan penatalaksanaan pelayanan yang dilakukan petugas IGD RS Prima Inti Medika sudah sesuai dengan SOP yang ditetapkan oleh rumah sakit dan sudah sesuai dengan Permenkes 856 atau akreditasi, tetapi IGD RS Prima Inti Medika masih memakai standard yang diberikan oleh Permenkes, selain itu persiapan penatalaksanaan pelayanan disesuaikan dengan visi misi rumah sakit yaitu memberikan pelayanan terbaik.

Menurut Kemenkes (2018) Akreditasi terhadap suatu produk atau layanan dianggap sangat penting sebagai indikator dari jaminan mutu. Operasional di setiap rumah sakit juga sangat beragam, tergantung dari metode kepemimpinan, infrastruktur dan dukungan teknologi informasi yang dimiliki. Karena keberagaman sistem pelayanan tersebut, Menteri Kesehatan Republik Indonesia membuat keputusan No.214/Menkes/SK/II/2007 mengenai Standarisasi Sistem Pelayanan Berstandar Internasional melalui Program Akreditasi. Definisi akreditasi rumah sakit dalam Peraturan Menteri Kesehatan Republik Indonesia Nomor 34 Tahun 2017 adalah pengakuan terhadap mutu pelayanan rumah sakit setelah dilakukan penilaian bahwa rumah sakit telah memenuhi standar akreditasi. Akreditasi dilaksanakan oleh lembaga independen penyelenggara akreditasi yang telah terakreditasi oleh lembaga International Society for Quality in Health Care (ISQua).

Lebih lanjut terkait proses pelayanan di IGD, tindakan petugas dalam penerimaan pasien IGD RS Prima Inti Medika sudah sesuai dengan instruksi yang diberikan dokter dan SOP yang ditetapkan oleh rumah sakit, seperti terlebih dahulu melakukan vital sign, persiapan alat-alat untuk pemasangan infus. Selain itu petugas IGD cepat respon terhadap pasien gawat darurat, dengan melakukan resusitasi terlebih dahulu untuk pasien jantung, melakukan pemeriksaan tanda-tanda vital, setelah itu hasilnya dikonsultasikan dengan dokter. Cara menyambut pasien gawat darurat sudah bagus. Disinilah pelayanan pertama kali yang diterima oleh seorang pasien saat tiba di rumah sakit, sehingga sangat menentukan kesan baik dan buruk dari rumah sakit tersebut. Hal ini sudah sesuai dengan prosedur penerimaan pasien.

Menurut Kelmanutu (2016), layanan kesehatan yang bermutu harus mampu memberikan informasi yang jelas tentang apa, siapa, kapan, dimana, dan bagaimana layanan kesehatan itu akan dan/atau telah dilaksanakan. Dimensi informasi ini sangat penting pada tingkat Rumah Sakit dan Puskesmas.

Dalam menghadapi keluhan pasien di IGD, petugas IGD sebelumnya sudah memberikan pengertian terlebih dahulu pada pasien terkait penyakit yang dideritanya, setelah itu melakukan anamnesa, kemudian menunggu instruksi dari dokter terkait tindakan selanjutnya. Tetapi menurut petugas ada juga keluhan pasien itu disebabkan pasien belum memahami proses treatmentdan terkadang keluarga pasien ikut campur dalam hal treatment tersebut.

Dari hasil wawancara dengan petugas IGD RS Prima Inti Medika pasca pelayanan di IGD setelah tindakan yang dilakukan di IGD menurut petugas apabila pasien tidak perlu dirujuk, pasien atau keluarga pasien diarahkan untuk menyelesaikan semua administrasi di kasir. Tapi sekiranya pasien tidak dapat ditangani di IGD dan tidak bisa ditangani oleh rumah sakit, maka pasien akan dirujuk. Pasca pelayanan oleh petugas IGD RS Prima Inti Medika sudah standard, pasien merasa puas terhadap pelayanan IGD RS Prima Inti Medika dan sebagai promosi bagi RS Prima Inti Medika.

Dari dukungan pelayanan yang ada di IGD RS Prima Inti Medika berdasarkan budaya kerja terlihat antara sesama perawat sudah terjalin hubungan kerja yang baik, hubungan petugas dengan dokter juga terjalin dengan baik. Ada kerjasama dan ada koordinasi antara sesama petugas IGD.

\section{Perspektif Pasien IGD RS Prima Inti Medika}

Perspektif pelanggan tentang kualitas layanan merupakan informasi yang penting bagi 
perusahaan jasa yang mencoba memperbaiki pelaksanaan bisnis, memperkuat diri menghadapi persaingan, dan memposisikan perusahaan secara strategis di pasaran. Proses suatu pelayanan yang berkualitas dimulai dari suplemen informasi dari produk dan jasa yang diperlukan oleh customer. Penyediaan saluran informasi memberikan kemudahan dalam rangka menjawab keingintahuan customer tersebut adalah penting.

Dari hasil wawancara dengan 3 orang pasien IGD RS Prima Inti Medika berdasarkan mutu pelayanan IGD dilihat dari pra pelayanan menurut ketiga pasien sudah sesuai dengan SOP yang ditetapkan oleh rumah sakit, penatalaksanaan sudah baik, sesuai espektasi dengan realita pasien. Pada proses pelayanan menurut pasien tindakan penerimaan dokter dan pelayanan farmasi sudah baik dan sudah sesuai. Pasien diberi informasi tentang kegunaan obat. Hal ini sesuai dengan Keputusan Dirjen Pelayanan Kefarmasian dan Alat Kesehatan No:HK.01.DJ.II.093 tentang Pedoman Pelayanan Informasi Obat di Rumah Sakit. Hal-hal yang perlu diinformasikan kepada konsumen kesehatan (pasien) antara lain, nama obat (merk dagang) dan kegunaanya, cara menggunakan (aturan pakai, dosis, serta waktu penggunaan), cara penyediaan obatnya, efek samping, pantangan selama penggunaan obat, cara penyimpanan obat, tindakan terhadap persediaan obat yang tersisa padahal sakit sudah dirasakan sembuh, tindakan apabila terjadi kesalahan dosis maupun kesalahan makan obat, dan tindakan pencegahan dari jangkauan anak kecil.

Tetapi menurut pasien yang pernah mendapatkan perawatan di IGD RS Prima Jaya Medika, pelayanan yang diberikan perawat dan fasilitas IGD masih kurang memuaskan. Pasca pelayanan,untuk penanganan selanjutnya terkesan lambat, harus dilakukan perawatan kembali karena masih ada pasien yang mengeluh karena bekas luka masih kotor. Oleh karena itu harus dilakukan perawatan kembali untuk menghindari infeksi.

Berdasarkan dukungan pelayanan yang ada di IGD RS Prima Inti Medika terlihat ada kerjasama antar perawat. Menurut Kelmanutu (2016) dalam memberikan pelayanan, hubungan antar manusia merupakan faktor yang berpengaruh langsung terhadap penilaian pasien tentang mutu pelayanan, sehingga apabila sikap petugas dalam memberikan pelayanan dapat memuaskan pasien maka pasien akan kembali memeriksakan kesehatannya ke Rumah Sakit.

Menurut Backer (1976) dalam Kelmanutu (2016) perlakukan yang kurang memuaskan atau kurang bijaksana serta sikap yang kurang baik menyebabkan pasien lari dari pengobatannya. Semakin baik hubungan antar manusia maka akan membuat pasien lebih patuh untuk menjalankan instruksi dari petugas kesehatan.

Selanjutnya jumlah perawat sudah sesuai, tetapi kompetensi dan kualitas perawat masih kurang. Tidak mungkin dalam proses perekrutan, manajemen sumber daya manusia bisa mendapatkan tenaga perawat sesuai dengan kualifikasinya. Seandainya pun ada tenaga perawat yang memenuhi kualifikasi, tentunya upah yang harus dibayarkan oleh rumah sakit pasti tinggi. Hal ini karena mereka mempunyai pengalaman yang lebih banyak dan mereka dikategorikan sebagai tenaga terdidik dan terlatih. Manajemen RS Prima Inti Medika harus mempunyai rencana pendidikan dan pelatihan tenaga keperawatan di IGD yang baik. Rencana pendidikan dan pelatihan tenaga keperawatan yang baik akan menghasilkan perawat yang berkualitas. Dengan jumlah perawat IGD yang optimal disertai dengan rencana pendidikan dan pelatihan tenaga keperawatan yang baik, diharapkan RS Prima Inti Medika mempunyai tim IGD yang mumpuni dan mampu memberikan pelayanan yang terbaik.

Berdasarkan uraian di atas maka pihak penyelenggara rumah sakit tidak ada pilihan lain selain berupaya untuk memberikan layanan terbaik kepada pasien, seluruh petugas layanan harus benar-benar memiliki kemampuan sesuai dengan bidang tugas mereka di rumah sakit. Petugas rumah sakit harus mewujudkan performance yang baik dalam bertugas, dapat memenuhi jadwal perawatan rutin kepada pasien, memberikan layanan yang cepat, sopan kepada pasien. Para petugas layanan memiliki kemampuan dalam memberikan informasi yang tepat tentang layanan yang diberikan pihak rumah sakit, sehingga pasien dapat memahami informasi dan pada waktunya informasi tersebut dapat membantu mereka.

Selanjutnya bagi tenaga medis diharapkan dapat meningkatkan efektifitas pelayanan kesehatan seperti dapat diatasinya masalah kesehatan secara tepat dan benar, kemudian dapat pula meningkatkan efisiensi pelayanan kesehatan, dalam hal ini ditujukan mencegah terjadinya pelayanan yang tidak sesuai dengan standar. Selain itu pula mereka diharapkan dapat meningkatkan penerimaan masyarakat terhadap pelayanan kesehatan, hal ini erat kaitannya dengan kesesuaian antara pelayanan kesehatan yang diselenggarakan dengan kebutuhan dan tuntutan pemakai jasa pelayanan. Diharapkan pula mereka mampu melindungi pelaksanaan pelayanan dari kemungkinan timbulnya gugatan 
hukum dari pasien, dalam hal ini maka mau tidak mau untuk melindungi munculnya gugatan hukum dari pasien yang tidak puas atas pelayanan kesehatan yang mereka terima maka tidak ada pilihan lain yang dilakukan kecuali menyelenggarakan pelayanan kesehatan yang terjamin mutunya (Eryanto, 2011).

\section{Manajemen IGD RS Prima Inti Medika}

Manajemen IGD RS Prima Inti Medika berdasarkan kompetensi teknis telah mengikuti standar layanan kesehatan yang telah disepakati yaitu meliputi kepatuhan, ketepatan, kebenaran dan konsistensi. IGD RS Prima Inti Medika sudah memiliki akses seperti parkir khusus untuk petugas maupun pasien. Selain itu petugas IGD RS Prima Inti Medika sudah menunjukkan kemampuan dalam mengurangi keluhan pasien. IGD RS Prima Inti Medika sudah memenuhi standar layanan kesehatan pada umumnya. Selanjutnya, IGD RS Prima Inti Medika telah dapat melayani pasien sesuai dengan kebutuhan. Tetapi keamanan layanan IGD RS Prima Inti Medika tergolong belum maksimal dan pasien tidak merasa nyaman saat dirawat di IGD RS Prima Inti Medika.

\section{SIMPULAN}

Dari hasil penelitian dan pembahasan maka dapat disimpulkan sebagai berikut:

1. Mutu Pelayanan IGD RS Prima Inti Medika

a. Persiapan awal sudah sesuai SOP yang ditetapkan rumah sakit, akses menuju IGD lancar. Sudah dilengkapi dengan penjelasan tentang penggunaan obat (edukasi).

b. Pada proses pelayanan respon perawat lebih cepat, perawat melakukan pemeriksaan tanda-tanda vital pasien pada proses pelayanan, obat yang diberikan sudah sesuai dengan instruksi dokter, keluhan pasien ditanggapi dengan baik oleh perawat dengan memberikan pengertian terlebih dahulu bagi pasien selanjutnya menunggu instruksi dokter.

c. Pasca pelayanan bagi pasien sembuh, keluarga diarahkan ke kasir, bagi pasien rawat inap diberikan therapy dan bagi pasien rawat jalan obat disiapkan terlebih dahulu. Proses rawat inap dan proses rujukan pasien, sudah bagus.

d. Berdasarkan dukungan pelayanan IGD Hubungan kerja sesama perawat berjalan baik, hubungan kerja perawat dengan dokter terjalin baik. Kompetensi petugas sudah terakreditasi. Jumlah dan kualitas perawat sudah sesuai. Fasilitas belum memadai. Imbalan masih dibawah ketetapan pemerintah.

2. Perspektif Pasien IGD RS Prima Inti Medika

a. Perspektif pasien berdasarkan pra pelayanan sudah sesuai dengan SOP yang ditetapkan oleh rumah sakit.

b. Pada proses pelayanan tindakan penerimaan dokter dan pelayanan farmasi sudah sesuai, tetapi pelayanan perawat dan fasilitas IGD masih kurang memuaskan.

c. Pasca pelayanan, penanganan selanjutnya terkesan lambat, harus dilakukan perawatan kembali karena bekas luka pasien masih kotor untuk menghindari infeksi.

d. Dukungan pelayanan yang ada di IGD RS Prima Inti Medika, Kerjasama antar perawat sudah bagus, jumlah perawat sudah sesuai, tetapi kompetensi dan kualitas perawatmasih kurang.

3. Manajemen IGD RS Prima Inti Medika

a. Manajemen IGD RS Prima Inti Medika berdasarkan kompetensi teknis telah mengikuti standar layanan kesehatan yang telah disepakati yaitu meliputi kepatuhan, ketepatan, kebenaran dan konsistensi.

b. IGD RS Prima Inti Medika sudah memiliki akses seperti parkir khusus untuk petugas maupun pasien.

c. Selain itu petugas IGD RS Prima Inti Medika sudah menunjukkan kemampuan dalam mengurangi keluhan pasien dan sudah memenuhi standar layanan kesehatan pada umumnya.

d. Selanjutnya, IGD RS Prima Inti Medika telah dapat melayani pasien sesuai dengan kebutuhan. Tetapi keamanan layanan IGD RS Prima Inti Medika tergolong belum maksimal dan pasien tidak merasa nyaman saat dirawat di IGD RS Prima Inti Medika 


\section{DAFTAR PUSTAKA}

Eryanto, H. (2011). Hubungan Antara Mutu Pelayanan dengan Kesetiaan Pasien (Survey pada Pasien Bagian Jantung Rumah Sakit Internasional Bintaro). Jurnal Ilmiah Econosains, 9(2), 107-118.

Green, Lawrence. (1980). Health Education: A Diagnosis Approach. The John Hopkins University: Mayfield Publishing Co.

Imam Sujono. (2015). Mutu Pelayanan Instalasi Gawat Darurat RSU BLUD Dr. H. Soemarno Sosroatmojo Tanjung Selor Tahun 2015. Tugas Akhir Program Magister (TAPM). Program Pascasarjana Universitas Terbuka. Jakarta.

Kelmanutu, L. S. (2016). Dimensi Mutu Pelayanan pada Unit Rawat Inap Rumah Sakit Umum Daerah Karel Sadsuitubun Langgur Kabupaten Maluku Tenggara.Media Kesehatan Masyarakat Indonesia, 9(4), 221229.

Kementerian Kesehatan Republik Indonesia. (2018). Data Dan Informasi: Profil Kesehatan Indonesia 2017. Jakarta.
Kementerian Kesehatan Republik Indonesia. (2017). Peraturan Menteri Kesehatan Republik Indonesia Nomor 34 Tahun 2017. Jakarta.

Mulyadi, D., Fadli, U. M., \& Ningsih, F. C. K. (2013). Analisis Manajemen Mutu Pelayanan Kesehatan pada Rumah Sakit Islam Karawang. Jurnal Manajemen, 10(3), 1203-1219.

Nena, A. F. D. A. (2015). Analisa Sistem Informasi Akuntansi Dalam Meningkatkan Pengendalian Internal Atas Pendapatan di Rumah Sakit Hermana-lembean. Jurnal EMBA: Jurnal Riset Ekonomi, Manajemen, Bisnis dan Akuntansi, 3(4).

Sugiyono. (2012). Metode Penelitian Kuantitatif Kualitatif dan R\&D. Bandung: Alfabeta.

Wibowo, Bambang. (2016). Peningkatan Akses Pelayanan Kesehatan yang Berkualitas. Direktur Jenderal Pelayanan Kesehatan. Rakerkernas 2016. Gelombang II. 